\title{
Cross-cultural adaptation of the Dental Neglect Scale for five-year-old children in Brazil
}

\section{Renata Cristina SOARES(a) \\ Simone Tetu MOYSÉS(a) \\ Juliana Schaia ROCHA ${ }^{(a)}$ \\ Márcia Helena BALDANI(b) iD \\ Renata Iani WERNECK(a) \\ Samuel Jorge MOYSÉS(a)}

(a)Pontifícia Universidade Católica do Paraná - PUCPR, School of Life Sciences, Dentistry Department, Curitiba, PR Brazil.

(b) Universidade Estadual de Ponta Grossa UEPG, Dentistry Department, Ponta Grossa, PR, Brazil.

Declaration of Interests: The authors certify that they have no commercial or associative interest that represents a conflict of interest in connection with the manuscript.

\section{Corresponding Author:}

E-mail: renatac.soares@hotmail.com

ht1ps://doi.org/10.1590/1807-3107bor-2021.vol35.0115
Renata Cristina Soares

\begin{abstract}
The aim of this study was to perform a cross-cultural adaptation of the Brazilian version of the Dental Neglect Scale (DNS). The process included (i) Translation; ii) Synthesis; iii) Back translation; (iv) Critical analysis by a committee of experts; (v) Pilot studies $\left(\mathrm{n}_{1}=30+\mathrm{n}_{2}=30\right)$; and (6) Evaluation and refinement of the instrument. The validated DNS presented a Content Validity Index (CVI) equal to 1.0 for the total score, as well as for each item. In the pilot studies, a minimum agreement level of $80 \%$ in understanding was achieved. DNS was properly adapted for Brazilian Portuguese, and it needs further study in a representative sample for reliability and construct validity assessment.
\end{abstract}

Keywords: Oral Health; Child; Dental Caries; Child Abuse.

\section{Introduction}

The Dental Neglect Scale (DNS) was created and tested in an Australian population to investigate the likelihood of occurrence of Child Dental Neglect (CDN), regarding dental issues. ${ }^{1}$ The DNS was applied in order to determine parental perception of their children's oral health and evaluate the extent of individual care in relation to oral health, the professional care received, the belief in the importance of oral health, as well as to increase the understanding of lay people regarding the etiology of dental caries in children. This scale was first applied in two age groups (10-11 and $14-15),{ }_{1}^{1}$ but it has been used with other ages since its original application. ${ }^{2,3}$

The age of five years is standardly used in national and international epidemiological surveys on caries ${ }^{4}$. In Brazil, according to the latest National Epidemiological Survey of Oral Health (2010), average caries experience was of 2.4 affected teeth. There was a reduction of only $13.9 \%$ in the seven years since the national survey of 2003. ${ }^{4}$ Therefore, based on the Brazilian epidemiological context, this age was selected for DNS validation. The aim of this study was to perform the cross-cultural adaptation of the Brazilian version of the DNS.

\section{Methodology}

Submitted: July 15, 2020

Accepted for publication: April 28, 2021

Last revision: May 17, 2021
The study was approved by the Research Ethics Committee of the Pontifícia Universidade Católica do Paraná ( $\mathrm{n}^{\circ}$ 2.361.906) and the Municipal 
Health Secretariat of Curitiba $\left(\mathrm{n}^{\mathrm{o}} 2.558 .218\right)$. The consent of the research participants was obtained.

The protocol suggested by Beaton et al. ${ }^{5}$ was used. Inclusion criteria of the study participants were: a) parents and/or caregivers of five-year-old children enrolled in municipal public schools in Curitiba, southern Brazil; and b) be literate and fluent in the Brazilian Portuguese language. Exclusion criteria were parents and/or caregivers who: a) were in mental health treatment; b) presented any limitation that could hinder communication with the researcher.

\section{Methodological steps (Figure)}

\section{Translations}

The original DNS was translated by two individuals fluent in English and native speakers of Brazilian Portuguese.

\section{Synthesis}

The researchers verified whether the two versions matched each other and reflected the content of the original scale, creating one synthesis version.

\section{Back-translation}

A native English speaker back-translated the synthesis version of the instrument from Brazilian Portuguese to English.

\section{Face and content validity steered by a}

multidisciplinary and bilingual experts committee

Thirteen professionals participated in this stage. Two approaches were used to gain consensus among the experts. Firstly, the expert committee performed the face and content validation qualitatively, through the individual analysis of the items, respecting the idiomatic, semantic, experiential, and conceptual equivalences among the available (re)translations.

Subsequently, the experts were asked to assess the clarity of each item in the instrument and the quantitative process was carried out, which included the calculation of the percent agreement among the experts and Content Validity Index (CVI). This index measures the proportion or percentage of experts who agree on certain aspects of the instrument and its items. ${ }^{6}$ To calculate CVI, the relevance attributed to each item was considered; for this, each expert was asked to consider the degree of association between the scale item and the theoretical construct (established by the DNS development team). The items were considered adequate at an agreement of $80 \%{ }^{7}$

Finally, to evaluate the overall agreement, the CVIs calculated for each item were added and divided by the number of items. ${ }^{6}$

\section{Pilot studies}

Two pilot studies were conducted, both with samples of 30 participants each. The samples were selected to resemble the profile of the target population. In the pilot study 1 , the version of the DNS resulting from the multidisciplinary committee consensus was evaluated, while in the pilot study 2 , a modified version was applied, according to the needed changes pointed out in the pilot 1 . Again, items with less than $80 \%$ agreement in understanding were reassessed. ${ }^{8}$

\section{Evaluation and refinement of the instrument}

Fine adjustments were made according to the needs indicated by the pilot study 2 , resulting in the final version of the instrument.

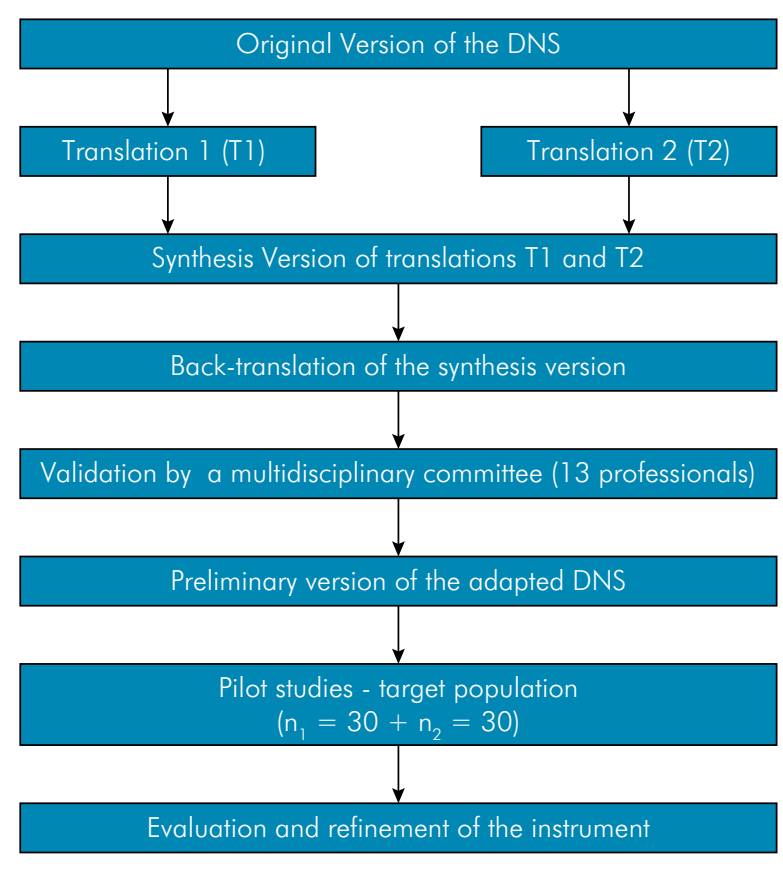

Figure. Flowchart of the adaptation process and validation of DNS to Brazilian Portuguese. 


\section{Results and Discussion}

DNS was translated as the "Escala de Negligência Odontológica" (ENO). Table shows the final version of the ENO.
The multidisciplinary committee consolidated the versions of the ENO in a single instrument for application to the target population. It was performed face validation regarding grammar, syntax, organization, adequacy, and logic; ${ }^{8}$ content

Table. Cross-cultural adaptation of the ENO for the Brazilian context.

\begin{abstract}
Original DNS items
Your child maintains his/her home dental care

Your child receives the dental care he/she should

Your child needs dental care, but you put it off

Your child needs dental care, but he/she puts it off

Your child brushes as well as he/she should

Your child controls between meal snacking as well as he/she should

Your child considers his/her dental health to be important
\end{abstract}

\title{
Synthesis of translations
}

Seu/ sua filho (a) realiza higiene bucal em casa

Seu/sua filho (a) recebe assistência odontológica que ele/ela precisa receber

Seu/sua filho (a) precisa de cuidados odontológicos, mas você deixa para depois

Seu/sua filho (a) precisa de cuidados odontológicos, mas ele/ela não quer ir ao dentista

Seu/sua filho (a) faz a higiene bucal como deveria ser feita

Seu/sua filho (a) controla as guloseimas entre refeições tão bem quanto deveria controlar

Seu/sua filho (a) compreende que a saúde bucal dele/dela é importante

\section{Back-translation}

Your son/daughter does his/her dental care at home

Your son/daughter gets the dental care that he/she needs to get

Your son/daughter needs dental care, but you put it off

Your son/daughter needs dental care, but he/she doesn't want to go to the dentist

Your son/daughter does his/her oral hygiene as he/she should

Your son/daughter controls sweets between meals as well as he/she should

Your son/daughter understands that his/her oral health is importante

\section{Pilot study I}

Sua criança cuida dos dentes em casa

Sua criança recebe os cuidados odontológicos que ele/ela deveria receber

Sua criança precisa de cuidados odontológicos, mas você deixa para depois

Sua criança precisa de cuidados odontológicos, mas ele/ela não quer ir ao dentista

Sua criança escova os dentes como deveria

Sua criança controla o consumo de doces entre as refeições como deveria

Sua criança considera que a saúde bucal dele/dela é importante

\section{Final version of the ENO}

Sua criança cuida dos dentes em casa

Sua criança recebe os cuidados do dentista que ele/ela deveria receber

Você deixa para depois os cuidados odontológicos que a sua criança precisa

Sua criança quer deixar para depois a ida ao dentista quando precisa de cuidados odontológicos

Sua criança escova os dentes como deveria

Sua criança controla o consumo de doces entre as refeições como deveria

Sua criança considera que a saúde bucal dele/dela é importante

Answer options in Portuguese: 1 - Não, com certeza; 2- Provavelmente não; 3- Não sei responder; 4-Provavelmente sim; 5- Sim, com certeza. 
validation was performed by appraising the degree to which each item represented the child dental neglect construct. Concerning relevance and clarity, all items presented an agreement higher than $80 \%$. Regarding the evaluation of the CVI, all items were classified as requiring 'little revision to be relevant' or 'relevant'.

Parents and/or caregivers of five-year-old children were chosen due to the importance they play in maintaining their children's health. Approaches focused on the interaction between children and their parents and caregivers are fundamental for promoting health. ${ }^{9}$ The subject covered by the ENO is complex and multifactorial; thereby, multiple aspects should be considered before the "accusatory" diagnosis of neglect - avoiding blaming the victims in some cases..$^{10}$ These characteristics make it difficult to define the ENO content, both because of the different explanatory models of neglect and because child neglect does not have a clear and unique definition of all the concepts involved in this construct.
Although the ENO has presented acceptable levels of validity and applicability, its final value must be tested. ${ }^{11}$ Therefore, further psychometric evaluations of this scale are required in the Brazilian context. The ENO is the only instrument that was developed in the area of child dental neglect, with higher scores of the scale indicating greater dental caries experiences. ${ }^{12}$

\section{Conclusion}

The results of this stage of the validation study contribute to the conceptual debate on cross-cultural adaptations. The application of the validated scale in a representative sample is required to obtain a complete assessment of the psychometric and statistical properties of the ENO.

\section{Acknowledgments}

This study was financed in part by the Coordenação de Aperfeiçoamento de Pessoal de Nível Superior Brasil (CAPES) - Finance Code 001.

\section{References}

1. Thomson WM, Spencer AJ, Gaughwin A. Testing a child dental neglect scale in South Australia. Community Dent Oral Epidemiol. 1996 Oct;24(5):351-6. https://doi.org/10.1111/j.1600-0528.1996.tb00875.x

2. Ajagannanavar SL, Sequeira PS, Jain J, Battur H. Dental neglect among college going adolescents in Virajpet. J Indian Asso Public Health Dent. 2014 Oct;12(3):10-3. https://doi.org/10.4103/2319-5932.144803

3. Skaret E, Astrøm AN, Haugejorden O, Klock KS, Trovik TA. Assessment of the reliability and validity of the Dental Neglect Scale in Norwegian adults. Community Dent Health. 2007 Dec;24(4):247-52.

4. Ministério da Saúde (BR). Secretaria de Atenção à Saúde. Secretaria de Vigilância em Saúde. Pesquisa Nacional de Saúde Bucal: resultados principais. Brasília, DF: Ministério da Saúde; 2012. (SP Brasil 2010).

5. Beaton D, Bombardier C, Guillemin F, Ferraz MB. Recommendations for the cross-cultural adaptation of the DASH \& QuickDASH outcome measures. Toronto: Institute for Work \& Health; 2007 [cited 2020 Apr 14]. Available from: http://www.dash.iwh.on.ca/sites/ dash/files/downloads/cross_cultural_adaptation_2007.pdf

6. Alexandre NM, Coluci MZ. Validade de conteúdo nos processos de construção e adaptação de instrumentos de medidas. Cienc Saúde Coletiva. $2011 \mathrm{Jul} ; 16(7): 3061-8$. https://doi.org/10.1590/S1413-81232011000800006

7. Wynd CA, Schmidt B, Schaefer MA. Two quantitative approaches for estimating content validity. West J Nurs Res. 2003 Aug;25(5):508-18. https://doi.org/10.1177/0193945903252998

8. DeVon HA, Block ME, Moyle-Wright P, Ernst DM, Hayden SJ, Lazzara DJ, et al. A psychometric toolbox for testing validity and reliability. J Nurs Scholarsh. 2007;39(2):155-64. https://doi.org/10.1111/j.1547-5069.2007.00161.x

9. World Health Organization. Global status report on preventing violence against children 2020. Geneva: World Health Organization; 2020 [cited 2021 May 17]. Available: https://www.who.int/teams/social-determinants-of-health/violence-prevention/global-status-rep ort-on-violence-against-children-2020

10. Bhatia SK, Maguire SA, Chadwick BL, Hunter ML, Harris JC, Tempest V, et al. Characteristics of child dental neglect: a systematic review. J Dent. 2014 Mar;42(3):229-39. https://doi.org/10.1016/j.jdent.2013.10.010

11. Jamieson LM, Thomson WM. The Dental Neglect and Dental Indifference scales compared. Community Dent Oral Epidemiol. 2002 Jun;30(3):168-75. https://doi.org/10.1034/j.1600-0528.2002.300302.x

12. McGrath C, Sham AS, Ho DK, Wong JH. The impact of dental neglect on oral health: a population based study in Hong Kong. Int Dent J. 2007 Feb;57(1):3-8. https://doi.org/10.1111/j.1875-595X.2007.tb00111.x 